\title{
Cytokines, Transcription Factors, and the Initiation of T-Cell Development
}

\author{
Hiroyuki Hosokawa and Ellen V. Rothenberg \\ Division of Biology and Biological Engineering, California Institute of Technology, Pasadena, California 91125 \\ Correspondence: hiroyuki@caltech.edu; evroth@its.caltech.edu
}

Multipotent blood progenitor cells migrate into the thymus and initiate the T-cell differentiation program. T-cell progenitor cells gradually acquire T-cell characteristics while shedding their multipotentiality for alternative fates. This process is supported by extracellular signaling molecules, including Notch ligands and cytokines, provided by the thymic microenvironment. T-cell development is associated with dynamic change of gene regulatory networks of transcription factors, which interact with these environmental signals. Together with Notch or pre-T-cell-receptor (TCR) signaling, cytokines always control proliferation, survival, and differentiation of early $T$ cells, but little is known regarding their cross talk with transcription factors. However, recent results suggest ways that cytokines expressed in distinct intrathymic niches can specifically modulate key transcription factors. This review discusses how stage-specific roles of cytokines and transcription factors can jointly guide development of early T cells.

$T^{\mathrm{h}}$ he thymus is the organ specialized to make $\mathrm{T}$ cells. T cells originate from hematopoietic stem and precursor cells in the bone marrow or fetal liver, which migrate to the thymus and acquire T-cell identity. Relatively small numbers of T-cell progenitors migrate into the thymus per day, but they respond to the new environment by undergoing multiple rounds of proliferation while initiating the T-cell differentiation program (Rothenberg 2000; Petrie and ZunigaPflucker 2007; Rothenberg et al. 2008; Love and Bhandoola 2011; Naito et al. 2011; Thompson and Zúñiga-Pflücker 2011; Rothenberg 2014; Yui and Rothenberg 2014). They then undergo T-cell lineage commitment, begin T-cell receptor (TCR) rearrangements, and thus generate $\alpha \beta T C R-$ or $\gamma \delta$ TCR-expressing T cells. The $\alpha \beta$ $\mathrm{T}$ cells further diverge into different sublineages, such as CD4 T cells, CD8 T cells, natural killer $\mathrm{T}$ (NKT) cells and regulatory $\mathrm{T}$ (Treg) cells, ultimately to act as a "conductor" of the immune system "orchestra."

Thymocytes are divided into multiple phenotypically distinct stages that are defined by the expression of CD4, CD8, and other markers (Hayday and Pennington 2007; Rothenberg et al. 2008; Yang et al. 2010; Naito et al. 2011; Yui and Rothenberg 2014). T-cell development is initiated from the subpopulation that lacks the expression of both CD4 and CD8, thus called double-negative (DN) cells, which then become $\mathrm{CD}^{+}{ }^{+} \mathrm{CD} 8^{+}$double-positive (DP) and subsequently differentiate into mature CD4 or CD8 single-positive (SP) cells. The earliest T-cell precursors in the thymus, called early thymic progenitor (ETP) or Kit-high doublenegative $1\left(\mathrm{KIT}^{++} \mathrm{DN} 1\right.$; CD $\left.44^{+} \mathrm{CD} 25^{-}\right)$, still harbor the potential to gain access to non-T

Editors: Warren J. Leonard and Robert D. Schreiber

Additional Perspectives on Cytokines available at www.cshperspectives.org

Copyright (C) 2018 Cold Spring Harbor Laboratory Press; all rights reserved; doi: 10.1101/cshperspect.a028621

Cite this article as Cold Spring Harb Perspect Biol 2018;10:a028621 
alternative fates. These cells start expressing T-cell markers in the next stage, DN2a $\left(\mathrm{KIT}^{++}\right.$ $\mathrm{CD} 44^{+} \mathrm{CD} 25^{+}$), but commitment to the T-cell lineage occurs only at the following stage, DN2b $\left(\mathrm{Kit}^{+} \mathrm{CD} 44^{+} \mathrm{CD} 25^{+}\right)$. Then in the DN3a $\left(\mathrm{KIT}^{-} \mathrm{CD} 44^{-} \mathrm{CD} 25^{+}\right)$stage, TCR $\beta$ gene rearrangement begins. This process enables some cells to express either a pre-TCR (TCR $\beta$ with invariant pre-TCR $\alpha$ ) or a $\gamma \delta$ TCR. Pre-TCRmediated signal transduction triggers transition of DN3a cells through DN3b into DN4 ( $\mathrm{Kit}^{-}$ $\mathrm{CD} 44^{-} \mathrm{CD} 25^{-}$), followed by progression to the DP stage. DP thymocytes undergo TCR $\alpha$ gene rearrangement and begin to express fully assembled $\alpha \beta$ TCR. Then, they are subjected to a selection process, which is known as positive selection, to identify cells that express TCR with potentially useful ligand specificities. Positively selected thymocytes are allowed to differentiate into either CD4 helper T cells or CD8 cytotoxic $\mathrm{T}$ cells, known as CD4/CD8-lineage choice.

The special feature of the thymic cortical environment is its dense presentation of Notch ligand, primarily Delta-like ligand 4 (DLL4) (Love and Bhandoola 2011). Very early in the ETP stage, T-cell precursors become not only influenced by Notch-DLL4 interaction but dependent on it for optimal growth and survival. NOTCH1 molecules on the surface of lymphoid precursors interact with DLL4 on thymic stromal cells, driving lymphoid precursors to initiate the T-cell-specific developmental program. Engagement of cell-surface NOTCH1 by environmental Notch ligands triggers the proteolytic release of intracellular NOTCH1, which travels to the nucleus to become a direct coactivator of DNAbound recombining binding protein suppressor of hairless (RBPJ) and stimulates the expression of Notch target genes (Radtke et al. 2010). All of the events that establish the T-cell identity of precursors are driven directly or indirectly by Notch signaling (Schmitt and Zuniga-Pflucker 2002; Thompson and Zúñiga-Pflücker 2011).

\section{THREE PHASES OF EARLY T-CELL DEVELOPMENT}

Early T-cell precursor development can be divided usefully into three phases in which the first two depend on Notch signaling and the third depends on signals from the pre-TCR. The first Notch-dependent phase involves the expansion of uncommitted T-cell precursors. The second Notch-dependent phase establishes the competence of the cells to express and depend on TCR complexes. The third phase, much less Notchdependent, expands cells with well-assembled pre-TCR complexes and prepares them for full immunological repertoire selection. These stages of differentiation are shown in Figure 1.

\section{Phase 1}

Under the influence of Notch signaling, the ETP cells that are derived from KIT ${ }^{\text {hi }}$ interleukin-7 receptor (IL-7R) ${ }^{\text {low }}$ precursors develop into KIT $^{\text {hi }}$ IL-7R ${ }^{\text {hi }}$ DN2a cells before undergoing Tcell commitment. Cytokines made by the thymic stroma act as growth factors for them and support extensive proliferative expansion of precommitment precursors (Love and Bhandoola 2011; Yui and Rothenberg 2014). Notch signaling not only turns on canonical Notch target genes such as Hes1, but also initiates the expression of the crucial T-cell specification factor coding genes Gata3 and Tcf7 (encoding TCF1 protein). Even before the cells are committed, ETP and DN2a cells begin to express some T-cell-specific genes. Together with Notch signaling, GATA3 and TCF1 antagonize the progenitor-specific factors in these pro-T cells and regulate specification and commitment of T cells (Rosenbauer et al. 2006; Hosoya et al. 2009; Germar et al. 2011; Weber et al. 2011; De Obaldia et al. 2013b; Garcia-Ojeda et al. 2013; Scripture-Adams et al. 2014).

\section{Phase 2}

Transcriptome analysis of developing $\mathrm{T}$ cells shows that the commitment-linked transition from phase 1 to phase 2 is marked by a large number of positive and negative gene regulation changes (Zhang et al. 2012). One element of these transcriptional changes is the activation of Bcl11b (Ikawa et al. 2010; Li et al. 2010a,b). BCL11B is a six zinc-finger transcriptional repressor that is turned on in the late DN2a stage by Notch signaling, TCF1, RUNX1, and 


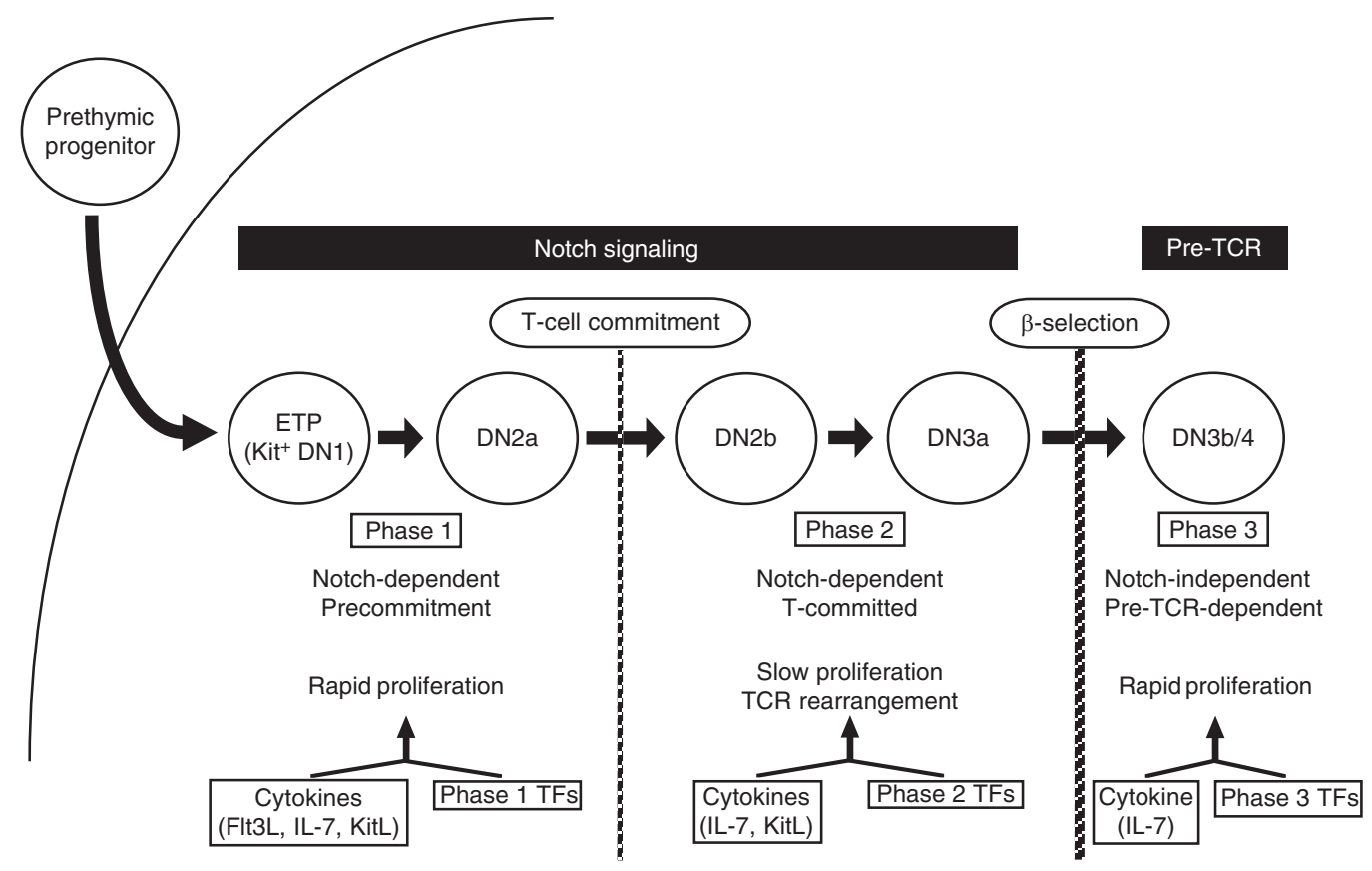

Figure 1. Roles of cytokines and transcription factors (TFs) in three phases of early T-cell development. Prethymic progenitor cells migrate into the thymus and begin T-cell differentiation program under the influence of Notch signaling. The earliest T-cell precursors in the thymus are called early thymic progenitor (ETP) or KIThigh double-negative $1\left(\mathrm{KIT}^{++} \mathrm{DN} 1 ; \mathrm{CD} 44^{+} \mathrm{CD} 25^{-}\right)$and they transit through DN2a, DN2b, DN3a, and $\mathrm{DN} 3 \mathrm{~b} / 4$ stages, followed by progression to DP stage. Early T-cell development can be divided into three phases based on the status of T-lineage commitment and Notch-dependency. The proliferation rate of the cells dynamically changes during the three phases and this reflects regulation by cytokine signaling and the phasespecific transcription factors. TCR, T-cell receptor; IL-7, interleukin-7.

GATA3 (Cismasiu et al. 2005; Tydell et al. 2007; Li et al. 2010b, 2013; Kueh et al. 2016). BCL11B is needed to finish the process of excluding cells from potential access to non-T-cell fates (Ikawa et al. 2010; Li et al. 2010a,b). It induces down-regulation of Kit expression, thus creating the DN2b phenotype, and direct binding of BCL11B at a possible Kit enhancer region may explain this ability to down-regulate Kit expression (H Hosokawa, HY Kueh, and EV Rothenberg, unpubl.). DN2b cells have a slower proliferation rate and begin to be desensitized to IL-7R signaling by a mechanism mediated by E proteins, and survival of DN2b cells becomes strictly Notch-dependent (Masuda et al. 2007; Wojciechowski et al. 2007; Yui et al. 2010). The subsequent DN3a stage is the peak period for expression of the Notch-dependent and E protein-dependent genes, such as recombina- tion activating gene 1 (Rag1), Rag2, Ptcra (encoding pre-TCR $\alpha$ ), and $C d 3 e$ (encoding CD $3 \varepsilon$ ) (Takeuchi et al. 2001; Ikawa et al. 2006; Schwartz et al. 2006; Georgescu et al. 2008; Welinder et al. 2011). Therefore, DN3a cells are committed to T-cell fate even before expressing TCR on their surface, but are primed both for TCR $\beta$ ( or TCR $\gamma$ and $T C R \delta$ ) gene rearrangement and for successful rearrangement to have an impact (Fig. 1).

\section{Phase 3}

The DN3a cells that have achieved successful $\mathrm{V}(\mathrm{D}) \mathrm{J}$ rearrangement for the TCR $\beta$ gene express pre-TCR and proceed to the DN3b stage. For DN2b and DN3a cells that rearrange both $T C R \gamma$ and TCR $\delta$ productively, a separate pathway leads to development of several functionally distinct subsets of $\gamma \delta \mathrm{T}$ cells (Prinz et al. 
2013; Vantourout and Hayday 2013). Although Notch signals are still required initially for passage through $\beta$-selection, cells that are able to receive signals through the pre-TCR transit from Notch-dependent to Notch-independent at this point. They strongly and rapidly turn off Notch target genes and IL-7R expression (Maillard et al. 2006; Taghon et al. 2006), becoming DN3b and then DN4 cells.

Signaling from pre-TCR triggers another shift in the gene regulatory network, transitioning into "phase 3." Despite the shutoff of IL-7Rand Notch-dependent growth-supporting systems, the DN4 cells enter a period of very rapid proliferation that is important for full phenotypic differentiation to the next stage (Kreslavsky et al. 2012). This is supported in part by chemokine signaling through CXCL12/ CXCR4 (Janas et al. 2010; Tussiwand et al. 2011). The proliferative burst also appears to be supported by very dynamic use of TCF1 and LEF1 in what may be a transient, self-limited canonical Wnt pathway response (Yu et al. 2010), although the details are still under debate. In the process, the cells begin to express not only the CD4 and CD8 coreceptors but also two new transcription factors, IKZF3 (Aiolos) and ROR $\gamma \mathrm{t}$, while finally silencing the last of the DN-specific factors, like ERG and HES1.

In summary, early T-cell development can be divided into three phases based on the status of T-lineage commitment and Notch dependency: Notch-dependent precommitted (phase 1), Notch-dependent T-lineage committed (phase 2), and Notch-independent pre-TCRdependent (phase 3) phases (Yui and Rothenberg 2014). Each of the phases is associated with distinct transcription factor ensembles that are supported by extracellular signaling provided from the microenvironment in the thymus. All three phases are essential for proper $\alpha \beta \mathrm{TCR}^{+} \mathrm{T}$-cell development.

\section{ROLES OF ENVIRONMENTAL SIGNALS AND TRANSCRIPTION FACTORS IN THE INITIATION OF T-CELL PROGRAM-PHASE1}

In phase 1 , early $\mathrm{T}$ cells need to rapidly proliferate to maintain the pool size of pro-T cells, because only small numbers of T-cell progenitors migrate into the thymus per day. The microenvironmental signals best established to support growth of initial thymic immigrants are Notch ligands and Kit ligand (also called stemcell factor $[\mathrm{SCF}]$ ). ETP cells have a NOTCH1 ${ }^{+}$ KIT $^{\text {hi }}$ IL-7R ${ }^{\text {low }}$ phenotype initially and only later develop into $\mathrm{NOTCH}^{+} \mathrm{KIT}^{\mathrm{hi}} \mathrm{IL}^{-7 \mathrm{R}^{\mathrm{hi}}}$ DN2a cells. Initially, the survival and proliferation of ETP cells mostly appear to be dependent on KIT/KIT ligand interaction (Waskow et al. 2002; Massa et al. 2006). Upon entry, thymic immigrants also express FLT3, but it seems to be down-regulated midway through the ETP stage, around the time when adult ETPs lose B-cell potential (Sambandam et al. 2005; Heinzel et al. 2007; Zhang et al. 2012; Mingueneau et al. 2013; Ramond et al. 2014). Although important prethymically, FLT3 does not appear to encounter its ligand in T-cell-promoting niches within the thymus. However, for cells escaping T-lineage commitment, FLT3 ligand may be important in much rarer, dendritic-cell-promoting intrathymic niches (Lyszkiewicz et al. 2015).

Notch1-DLL4 signaling is not only needed for viability and to induce genes encoding Tcell-specific regulatory factors, such as Tcf7, Gata3, and Bcll1b, but it is also required to antagonize alternative non-T-lineage development through a variety of pathways. A particularly sensitive target is the B-cell pathway (Mohtashami et al. 2010; Van de Walle et al. 2011), which may be blocked by Notch signaling through at least two distinct mechanisms (see below) (Hozumi et al. 2008). After this, ETP and DN2a cells still retain the potential to develop into dendritic cells, granulocytes, macrophages, and innate lymphocytes (ILCs), including NK cells and possibly mast cells (Shen et al. 2003; Schmitt et al. 2004; Balciunaite et al. 2005b; Taghon et al. 2007; Bell and Bhandoola 2008; Wada et al. 2008; Luc et al. 2012; Wong et al. 2012; De Obaldia et al. 2013a), but then all of these potentialities are also shut off at the transition from DN2a to DN2b under the continued influence of Notch signaling, as described below.

In view of their differential expression of KIT and IL-7R, it is notable that both ETP and 
DN2a cells proliferate extensively before commitment, and both KIT ligand and IL-7 from the thymic microenvironment are crucial for this early expansion (Prockop and Petrie 2004; Massa et al. 2006; Calderon and Boehm 2012; Buono et al. 2016). This proliferation is driven first by a KITL-predominant microenvironment and then by an IL-7-predominant environment (Buono et al. 2016), matching the shifts in the ratio of KIT to IL-7R as the cells progress from ETP to DN2a cells. However, computational modeling suggests that the largest number of cell cycles may take place in the ETP stage (Manesso et al. 2013), before the cells activate strong expression of IL-7 receptors. This suggests that the earliest proliferative expansion could be a major function that depends not only on KIT signaling but also on another regulatory input in place of IL-7R, and one possibility is that this is supplied by the phase 1 -specific transcription factors. Many of the transcription factors that are expressed only in phase 1 have roles in the proliferation, survival, and self-renewal of other hematopoietic cells and can be involved in the pathogenesis of leukemias (Yui and Rothenberg 2014).

Two phase 1-restricted transcription factor genes that have clear genetically defined roles in ETP-DN2-stage proliferative expansion are Lyl1 (Zohren et al. 2012) and Hhex (Goodings et al. 2015; Jackson et al. 2015), whereas the factor encoded by a third gene, $\mathrm{Erg}$, is specifically implicated in proliferation at the expense of differentiation (Knudsen et al. 2015). In addition, even PU.1 (encoded by Spil, also known as Sfpi1), a phase 1-restricted transcription factor that seems most associated with alternative differentiation pathways, may also positively regulate growth of phase 1 pro-T cells, directly or indirectly. The expression of PU.1 continues in early DN cells from their prethymic precursors, persisting at high levels through multiple cell divisions in ETP and DN2a stages, but then decreasing sharply during T-cell lineage commitment (Yui et al. 2010). PU.1 is normally associated with the differentiation of dendritic cells (DCs), myeloid cells, and B cells, and its expression strongly correlates with the ability of uncommitted T-cell precursors to differentiate to DC and myeloid cell fates when Notch signaling is withdrawn (Lefebvre et al. 2005; Franco et al. 2006; Laiosa et al. 2006; Carotta et al. 2010b; Del Real and Rothenberg 2013). However, in addition, it is important for the expression of FLT3 by prethymic precursors (Carotta et al. 2010a), and direct genomic analysis indicates that it regulates numerous G-protein-coupled receptors and signaling components as well as cytokine receptors in phase 1 pro- $\mathrm{T}$ cells (Champhekar et al. 2015). Any of these could help to explain how PU.1 also positively contributes to early T-cell development (Dakic et al. 2005; Champhekar et al. 2015).

\section{GATA3 AND THE ESTABLISHMENT OF A T-CELL-SPECIFIC REGULATORY STATE}

Despite the presence of non-T lineage factors, phase 1 is also the context in which the T-cell program is first triggered. Notch signaling in ETP cells initiates the expression of the crucial regulatory transcription factor genes Gata3 and $T c f 7$, which then alter the developmental status of the cells (Hosoya et al. 2009; Germar et al. 2011). Tcf7 is activated by Notch signaling directly, and its product, TCF1, primarily acts as a positive regulator of T-cell specification, collaborating with Notch to activate T-cell genes through a feedforward network circuit (De Obaldia and Bhandoola 2015). GATA3 and TCF1 (encoded by Tcf7) not only begin to antagonize the progenitor-specific factors, but they also collaborate with a different group of regulatory factors required for T-cell development that continue expression initiated from a prethymic stage, such as MYB, RUNX1, CBF $\beta$, IKAROS, GFI1, and E2A. These are stably expressed as "legacy factors," but nevertheless function in developmentally modulated ways, as they are incorporated together with TCF1 and GATA3 into the network of factors regulating T-cell lineage commitment. Actually, some of these factors have also been identified as physically GATA3-interacting molecules in an early T-cell line (H Hosokawa and EV Rothenberg, unpubl.).

GATA3 has indispensable roles not only in early T-cell development but also throughout 
H. Hosokawa and E.V. Rothenberg

T-cell development, with multiple functions in the thymus and periphery. It works differently in a broad variety of developmental stages, affecting early T-cell survival, growth, specification, and commitment and in priming DN2 cells for progression to $\beta$-selection (Pai et al. 2003; Hosoya et al. 2010; Garcia-Ojeda et al. 2013; Scripture-Adams et al. 2014; Tindemans et al. 2014). In one of the earliest steps in commitment, Notch signaling- and TCF1-induced Gata3 expression blocks B-cell lineage developmental potential from ETP cells, very shortly after their immigration into the thymus (Heinzel et al. 2007; Hozumi et al. 2008; Garcia-Ojeda et al. 2013).

The levels of GATA3 gradually increase in DN2a-DN2b cells and contribute to both activation of Bcl11b and repression of Sfpil (PU.1) expression to support T-cell specification and commitment (Taghon et al. 2007; Zhang et al. 2012; Li et al. 2013). Knockdown of Gata3 expression in ETP and DN2 cells blocks appearance of the DN3 phenotype, with up-regulation of phase 1 genes, including Sfpil and Bcl11a, and down-regulation of phase 2 genes, such as Ets1, Zfpm1, Il9r, Il17rb, and Bcl11b (Garcia-Ojeda et al. 2013; Scripture-Adams et al. 2014). Later, GATA3 is also required for full TCR $\beta$ locus activation needed to pass through $\beta$-selection, and for generation of CD4 SP T cells (Pai et al. 2003).

Therefore, GATA3 is a vitally important factor for early T-cell development, but at least in the murine system, it has a highly limited doseresponse range in DN cells. This is an interesting contrast with its roles in mature Th2 cells, where overexpression is tolerated. Instead, increased concentrations of GATA3 are as toxic for mouse early T-cell precursors as loss of GATA3, and if the overexpressing cells can be kept alive, they can be driven into becoming mast cells (Taghon et al. 2007). Thus, T-cell identity is strongly dependent on GATA3 and also requires the preservation of strict limits to GATA3 expression.

While GATA3 at modest levels is nearly universal in T-lineage precursor cells from the ETP stage onward, its activity may be modulated in a stage- or signal-dependent way. Recently, several groups reported that posttranslational modifications of GATA3 regulate its functions (Cook and Miller 2010; Kitagawa et al. 2014; Hosokawa et al. 2015, 2016). Phosphorylation and acetylation regulate both stability and transcriptional activity of the related GATA1 factor (Hernandez-Hernandez et al. 2006). Thus, the functions of GATA3 could be strictly regulated by several distinct mechanisms in a stage-specific manner.

\section{AVOIDING DIVERSION TO ALTERNATIVE FATES IN PHASE 1}

Phase 1 cells, still being uncommitted, need continuous signaling from the microenvironment to stay in the T-cell pathway. Each kind of alternative pathway needs to be obstructed by a different mechanism. Within the thymus, Notch-DLL4 signaling rapidly induces antagonists of at least two alternative pathways, GATA3 to block B-cell development and HES1 to block myeloid development (De Obaldia et al. 2013b; Garcia-Ojeda et al. 2013; Scripture-Adams et al. 2014). Notch-induced TCF1 may also play a role in blocking access to DC development, at least (Kueh et al. 2016). Eventually, the cumulative action of the Notch-triggered regulatory cascade also induces BCL11B (Kueh et al. 2016) to block NK cell development (Li et al. 2010b). The up-regulation of these active antagonists of alternative fates can be viewed as "commitment by addition.” The possibility of diversion to myeloid and dendritic cell fates is not eliminated at a cell-intrinsic level, however, until the cells transition to phase 2, through "commitment by subtraction," when the key enabling factor PU.1 is silenced. Until then, very selective expression of cytokines in the thymus microenvironment also provides a safety net. B cells can potentially grow in the IL-7 provided by cortical thymic epithelial cells (Calderon and Boehm 2012), if not aborted early by Notch-dependent mechanisms, but progenitors taking a pathway that might require myeloid growth factors cannot expand in the normal thymus where such factors are largely absent (Lyszkiewicz et al. 2015). In fact, these environmental restrictions are extremely effective, so that the majority of phase 1 cells appear not to give rise to any de- 
tectable myeloid progeny in vivo as long as their development in the thymus is undisturbed (Schlenner et al. 2010).

Other cytokines besides myeloid growth factors must also be kept away from developing pro-T cells. A fraction of phase 1 cells can respond to the addition of cytokines IL-33 and IL-7 in the presence of Notch signaling to become ILC2 (Wong et al. 2012). Signals from IL-33 can redirect the effects of transcription factors such as GATA3, BCL11B, and TCF1 to work in the ILC2 program, via induction of $I d 2$ and the gene that encodes orphan nuclear receptor $\operatorname{ROR} \alpha$ (Hoyler et al. 2012; Wong et al. 2012; Yang et al. 2013; Walker et al. 2015; Yu et al. 2015; Zhong and Zhu 2015). Id2 expression is required to develop all types of ILCs, which do not use RAG-based gene rearrangement in their development program. ILCs keep the Rag genes off, at least in part because of neutralization of E protein activity by Id2 (Diefenbach et al. 2014; De Obaldia and Bhandoola 2015; Serafini et al. 2015). In contrast, high levels of BCL11B, exceeding those in any ILC subset, restrain $I d 2$ expression in cells taking the Tcell pathway (Longabaugh et al. 2017).

\section{PROLIFERATION AND DIFFERENTIATION IN THE PHASE 1/PHASE 2 TRANSITION: ROLES OF IL-7/IL-7R SIGNALS}

IL-7 plays a key role in the development of early T cells. Actually, mice lacking IL-7 or IL-7R show strongly impaired T-cell development (Peschon et al. 1994; DiSanto et al. 1995; von Freeden-Jeffry et al. 1995), and IL-7R-deficient T-cell precursors cannot fill available thymic niches (Prockop and Petrie 2004; Zietara et al. 2015). Defects in the IL-7R in human are associated with a severe combined immunodeficiency syndrome characterized by a complete lack of T cells (Noguchi et al. 1993; Puel et al. 1998). IL-7 signaling also has critical roles in both $\gamma \delta \mathrm{T}$-cell development and in later CD8 lineage choice via induction of transcription factor Runx3 (Singer et al. 2008).

IL-7R is strongly up-regulated in DN2a, and the proliferative expansion of the cells at this stage becomes highly sensitive to the IL-7 level
(Wang et al. 2006). In addition, however, its signaling modulates the rate of developmental progression (Balciunaite et al. 2005a; Huang et al. 2005), and this implies an interaction with the T-cell specification gene-regulatory network. IL-7R signaling activates both signal transducers and activators of transcription (STAT)5 and phosphatidylinositol 3-kinase (PI3K) pathways. Both pathways are important: the PI3K pathway plays a crucial role in proliferation and survival of early T cells (Pallard et al. 1999) and STAT5A/5B are needed for full population expansion both before and after $\beta$-selection (Yao et al. 2006), as well as being indispensable for opening of the Tcrg loci for rearrangement to allow $\gamma \delta$ T-cell development (Ye et al. 2001; Kang et al. 2004). Surprisingly, though, little is known about any other ways that STAT5A/5B interact with the genes in the T-cell specification gene network.

Two unresolved questions are: first, whether IL-7R contributes to the extensive proliferation that seems to occur in ETPs before IL-7R expression is detectable; and, second, why KIT and IL-7R signaling activate less rapid proliferation in DN2b cells than in DN2a cells despite similar expression of IL-7R. One report has suggested that KIT and IL-7R can interact physically and signal as a complex (Jahn et al. 2007). If responses to IL-7R are actually responses to an IL-7R/KIT complex, then a high level of KIT coexpression, only available in phase 1 cells, may be required to support full IL-7-mediated proliferation. Alternatively, IL-7R signaling may depend on phase 1 transcriptional regulatory factors to induce proliferation of early $\mathrm{T}$ cells.

Desensitization of IL-7R after the phase 1phase 2 transition may be important in part because of cross talk of IL-7 signaling with transcription factors. There are positive and negative interactions of IL-7/IL-7R signals with key T-cell transcription factors. First, IL-7R-mediated PI3K/AKT signaling has been reported to induce phosphorylation of GATA3 in memory Th2 cells (Hosokawa et al. 2016), and AKT-mediated phosphorylation of GATA3 regulates organization of GATA3 complexes. Strict regulation of GATA3 expression and function is important for survival and proliferation of 
early T cells; thus, IL-7R-mediated phosphorylation of GATA3 may have some role in stagespecific responses to IL-7. Second, IL-7/IL-7R signaling is known in some conditions to reduce expression of genes, including Tcf7, Lef1, and $B c l 11 b$, encoding some phase 2 transcription factors that have important roles in the phase 2 regulatory network (Yu et al. 2004; Ikawa et al. 2010). This interaction may underlie the ability of high IL-7 to slow developmental progression to the DP stage, especially in cells developing from adult ETPs and bone marrow precursors (Balciunaite et al. 2005a; Huang et al. 2005).

Despite its relative desensitization during DN2b and DN3a stages, IL-7R activity remains a latent contributor to cell survival as long as $I l 7 r$ is expressed. As cells enter $\beta$-selection, IL$7 \mathrm{R}$ signaling from existing cell-surface receptors still provides some support for proliferation and survival of DN3b and DN4 cells, even as transcription of $I l 7 r$ itself is finally repressed. At this stage, IL-7/IL-7R signaling enhances survival and proliferative expansion via induction of prosurvival factor $\mathrm{Bcl} 2$ and by sustaining expression of nutrient-transport protein-coding genes, such as $C d 98$ and $C d 71$ (Boudil et al. 2015). Therefore, sensitivity and reactivity to IL-7 are dramatically changed in three phases.

\section{ROLES OF CYTOKINES AND} TRANSCRIPTION FACTORS IN THE COMMITMENT OF T-CELL LINEAGE CELLS-PHASE 2

Right after Bcl11b expression is induced by the combination of Notch signaling, RUNX1, GATA3, and TCF1 cells transition to the DN2b stage (Yui et al. 2010; Li et al. 2013; Kueh et al. 2016). DN2b cells proliferate more slowly than DN2a, and their survival becomes strictly Notch-dependent (Yui et al. 2010). It is still not certain whether BCL11B directly represses most phase 1 regulatory genes or simply disables signaling that would otherwise maintain their expression (Longabaugh et al. 2017); but in either case, its action allows most phase 1 -restricted genes to be silenced and enables the cells to enter a committed DN2b state (Ikawa et al. 2010; Li et al. 2010a,b).
As DN2a cells progress into the DN2b stage, they undergo dynamic shifts in the expression of other transcription factors as well. These are currently useful landmarks although their functional significance is still not fully understood. Some of the largest shifts are reciprocal regulation of members of the same factor family. For example, two ETS family transcription factor genes, Ets1 and Ets2, are rapidly turned on as the ETS family gene Sfpil is turned off; Gfil is turned on as Gfilb is turned off; Bcl11b is turned on as Bcl11a is turned off, and Runxl increases expression as Runx2 and Runx 3 decrease (David-Fung et al. 2009). The silencing of Sfpil expression, through a mechanism dependent on RUNX factors and possibly GATA3 (Taghon et al. 2007; Huang et al. 2008; Zarnegar et al. 2010; Scripture-Adams et al. 2014), is thought to be one of the molecular mechanisms of alternative lineage exclusion as noted above.

Several mechanisms can amplify Notch pathway signaling in DN3a cells. In addition to Notch1, Notch3 is activated at DN3a, largely by a NOTCH1-derived signal, and this probably adds to the sensitivity for Notch pathway signaling. At the same time, the cells become desensitized to IL-7R-driven mitogenesis in a process that depends on the basic helixloop-helix $\mathrm{E}$ protein transcription factors, E2A and HEB (Wojciechowski et al. 2007). Whereas E2A (encoded by Tcf3) is expressed stably, HEB levels (encoded by Tcf12) increase steadily through the DN stages so that an increasing amount of E2A/HEB heterodimer can be formed, which is important for $\beta$-selection (Barndt et al. 2000; Braunstein and Anderson 2012). The activity of E2A and HEB may be further boosted in DN3a by the silencing of a competitive binding partner, $L y l 1$, one of the phase 1 genes (Zhong et al. 2007; Yui et al. 2010). E proteins in T-cell precursors work in collaboration with Notch signals (Ikawa et al. 2006), not antagonistically as proposed in $B$ cells (Nie et al. 2008), and Notch signaling levels can only be sustained in this context by strong $\mathrm{E}$ protein activity (Yashiro-Ohtani et al. 2009; Del Real and Rothenberg 2013). Expression of E protein-dependent and Notch-dependent genes, including Ptcra, Rag1, Rag2, terminal de- 
oxynucleotidyl transferase (Dntt) and Cd3e, markedly increases as the proliferation slows and the cells proceed to the DN3a stage (Takeuchi et al. 2001; Ikawa et al. 2006; Schwartz et al. 2006; Georgescu et al. 2008; Welinder et al. 2011; Xu et al. 2013).

The E proteins also activate expression of growth-inhibitory factors, such as suppressor of cytokine signaling 1 (Socs 1 ) and Socs3, which uncouple growth factor receptors like IL-7R from their signaling pathways. In parallel, they can directly inhibit cell-cycle activation genes, and induce cyclin-dependent kinase inhibitors (Schwartz et al. 2006). The cell-cycle arrest induced by $\mathrm{E}$ proteins is important to enable RAG1/RAG2-mediated recombination of the TCR genes to take place (Li et al. 1996) as well as for checkpoint control. Double knockout of the genes encoding E2A ( Tcf3) and HEB (Tcf12) in DN3 stage not only prevents proliferative arrest but also enables DN3 cells to undergo reverse differentiation to return to a highly IL7-responsive, DN2-cell-like phenotype (Wojciechowski et al. 2007). However, E protein effects on TCR expression go beyond their effects on the cell cycle. Singly, E2A ( Tcf3)-deficient cells have a specific defect in TCR $\beta$ gene rearrangement (Agata et al. 2007) and are prone to leukemic transformation (Engel and Murre 2004).

To summarize, DN3a cells generated by phase 2 regulatory processes are committed to a T-cell fate that is $\alpha \beta$ lineage biased and primed for RAG-mediated TCR $\beta$ gene rearrangement. To reach this stage, cells require Notch signaling, GATA3, TCF1, BCL11B, ETS1, RUNX1, and E2A (Oosterwegel et al. 1991; Schwartz et al. 2006; Li et al. 2010a,b; Germar et al. 2011; Zhang et al. 2012; Xu et al. 2013). The maximal expression of the $C d 3$ gene cluster is regulated by $\mathrm{E}$ protein, GATA3, TCF1, and BCL11B, whereas the Rag genes are induced by E protein and GATA3. Together with Notch signaling, several transcription factors are involved in TCR $\beta$ gene rearrangement such as E2A, HEB, MYB, GATA3, and RUNX1. ETS1 collaborates with RUNX1 to activate the enhancer of the TCR $\beta$ gene ( $\mathrm{Gu}$ et al. 2000). The expressions of Hes 1, Notch3, and Ptcra are jointly regulated by E protein and Notch signaling. E proteins are required to promote and sustain NOTCH1 expression in DN3a stage, and Notch signaling can be antagonized by the $\mathrm{E}$ protein antagonist Id2. BCL11B at a high level keeps $I d 2$ expression silent and assists activation of Dntt and the $C d 3$ gene cluster (Longabaugh et al. 2017) to support transition to the DN3a state. Thus, most of the T-cell genes are fully activated, and cell-cycle arrest is induced, by late phase 2 stage. At this stage, RAG1/RAG2-mediated programmed TCR $\beta(\mathrm{V}(\mathrm{D}) \mathrm{J} \beta)$ gene rearrangement also takes place. In the mouse, only a minority of phase 2 cells rearrange the Tcrg and Tcrd genes instead. The cells expressing a functional pre-TCR on productive rearrangement of the Tcrb gene are able to pass through the $\beta$-selection checkpoint.

\section{ROLES OF TRANSCRIPTION FACTORS IN PASSING THE $\beta$-SELECTION CHECKPOINT TO PHASE 3}

Signaling through the newly expressed pre-TCR not only disrupts the quiescence of DN3a cells, but also rapidly shuts off the expression of Notch target genes in an IKAROS-dependent manner, and cells proceed to phase 3 (Chari and Winandy 2008; Kleinmann et al. 2008; Geimer Le Lay et al. 2014). The burst of proliferation that takes place on $\beta$-selection amplifies clones of cells with productive Tcrb rearrangements to maximize the chance for productive $\mathrm{TCR} \alpha \beta$ diversity. At the same time, it helps $\alpha \beta$ $\mathrm{T}$ cells to undergo proliferation-dependent epigenetic changes and to dilute out previous stores of regulatory molecules that would otherwise interfere with their new regulatory state (Kreslavsky et al. 2012). Notch signaldependent transcription becomes dispensable, and many of the transcription factors that participated in the phase 1 and phase 2 stages decrease or disappear (Tabrizifard et al. 2004; Yui and Rothenberg 2004). As cells become DP thymocytes, repressive histone marks accumulate at the promoters of phase 1 and Notch target genes (Zhang et al. 2012; Vigano et al. 2014), whereas other sites open (e.g., a set of DP-specific sites for ETS1) (Cauchy et al. 2015). The establishment of durable epigenetic changes at 
the T-cell and non-T-cell gene loci makes the program of $\mathrm{T}$-cell gene expression sustained and irreversible (Zhang et al. 2012; Vigano et al. 2014).

As the cells proliferate and become DP, in response to a combination of TCF1 and $\beta$ catenin, with a required input from MYB, the cells distinctively activate expression of two new factors: RORyt (Rorc) and the Ikaros zinc-finger family member AIOLOS ( $I k z f 3$ ). Although most universal T-cell properties have already been acquired by the cells, they need a special form of viability support to keep them alive in DP stage long enough to undergo several rounds of TCR $\alpha$ gene rearrangement. The combination of MYB, TCF1, high HEB/E2A, and ROR $\gamma t$ helps to induce BCL-XL (Bcl2l1) expression in the future DP cells to sustain them through this process (Sun et al. 2000; D'Cruz et al. 2010; Yuan et al. 2010; Wang et al. 2011) and to arm them for positive selection. Thus, a new regulatory state prepares DP thymocytes for the complex positive and negative selection events that they must undergo.

\section{REGULATING T-CELL PRECURSOR FLUX: GLIMPSES INTO THE EARLIEST PORT OF THYMOCYTE ENTRY}

One domain in which microenvironmental cues may be most important for controlling T-cell generation remains relatively mysterious. This is the initial entry port for immigrants into the thymus. Early T-cell development is coordinated with migration through distinct thymic microenvironments (Fig. 2) (Petrie and ZunigaPflucker 2007; Love and Bhandoola 2011). In postnatal mammals, immigrant precursors initially enter the thymus through blood vessels near the corticomedullary junction (Fig. 2, right), drawn possibly by chemokine receptor signaling from CCR7 and CCR9 (Uehara et al. 2002; Schwarz et al. 2007; Krueger et al. 2010; Zlotoff et al. 2010). Although the numbers of cells involved are small, it appears that ETP cells undergo expansion with minimal differentiation in this corticomedullary junction region, and then, days later, differentiate into DN2a cells that can begin their migration from the site of entry deep within the cortex to the outer rim of the cortex. $\beta$-selection occurs during the accumulation of the DN3 cells when they reach the extreme outer portion of the thymus. A directional reversal of migration back across the cortex toward the medulla occurs for the later stages of thymocyte development. Thus, for example, the different requirements for IL-7 may be accommodated in vivo by varying amounts of IL-7 in combination with other extracellular signals, including adhesive molecules, chemokines, and cytokines provided by different microenvironments (Zamisch et al. 2005; Alves et al. 2009; Griffith et al. 2009; Love and Bhandoola 2011).

This pattern is different in the early fetal thymus, where precursors enter directly into the thymic rudiment by migrating across the mesenchyme from the outside, before the organ is vascularized and before the capsule forms a barrier (Fig. 2) (Anderson et al. 2006). In the fetus, elegant mutant-rescue experiments indicate that the crucial genes that the epithelium must express to support T-cell differentiation are DLL4, KIT ligand (KITL), CXCL12, and CCL25 (i.e., ligands for NOTCH1, KIT, CXCR4, and CCR9, respectively) (Calderon and Boehm 2012). However, it is not clear that this fetal environment behaves equivalently to the postnatal one. First-wave fetal thymocytes differentiate faster than late-fetal or postnatal thymocytes (Watanabe et al. 1997; Ramond et al. 2014; Scripture-Adams et al. 2014), and they begin to carry out TCR gene rearrangement after fewer rounds of proliferation once they have entered the thymus ( $L u$ et al. 2005). At least part of this difference is cell-intrinsic, because fetal thymocytes also differentiate faster when they are compared on the "level playing field" of the OP9-DLL1 artificial stroma coculture system (Schmitt and Zuniga-Pflucker 2002), and there are subtle but real differences in gene expression at corresponding developmental stages (David-Fung et al. 2006; Belyaev et al. 2012; Ramond et al. 2014; Scripture-Adams et al. 2014). First-wave fetal thymocytes also rearrange a particular subset of TCR $\gamma$ genes that are almost never used after birth. However, in the adult thymus, the specific transition from 

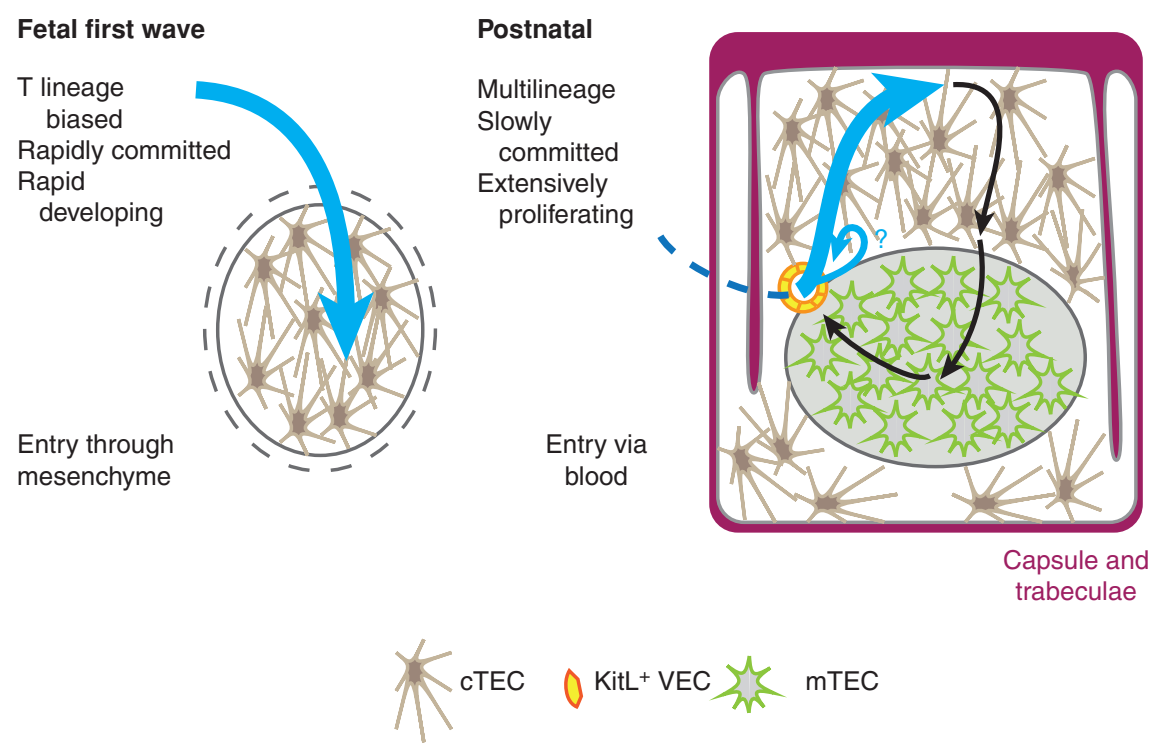

Figure 2. Fetal and postnatal pathways for progenitor entry into the thymus. Thymic epithelial function is established in embryonic life and maintained through postnatal life by genes controlled by the FOXN1 transcription factor, but the interactions between the thymic microenvironment and immigrating T-cell precursors are not the same in fetal and adult life. (Left) Schematic showing pathway of entry and cells involved in interactions of initial wave of T-cell precursors with the E12-14 fetal mouse thymic microenvironment. (Right) Same for pathways and interactions between postnatal T-cell precursors and the young adult (4-8 wk old) mouse thymus. Emphasis is on the cortex where progenitors undergo T-lineage commitment and the interactions controlling traffic into this domain. Medullary structure (pale green, right panel only) develops after the entry of the first-wave fetal thymic immigrants. Cyan arrows: major pathways of entering precursors, through Tcell lineage commitment. A thin cyan arrow indicates possible self-renewal pathway within entry compartment (right). Thin black arrows represent locations of T-cell receptor (TCR)-dependent phases of T-cell development in the postnatal thymus (right): $\beta$-selection, positive selection in the cortex leading to migration into the medulla, and medullary maturation events including selection and preparation for export. Locations of cortical thymic epithelial cells (cTEC), $\mathrm{KITL}^{+}$vascular endothelial cells $\left(\mathrm{KITL}^{+} \mathrm{VEC}\right)$, medullary thymic epithelial cells (mTEC), and the connective tissue elements of the thymus (capsule and trabeculae, right panel only) are indicated. See text for details.

ETP to DN2 is disproportionately slower than in the fetus. In steady state, postnatal mouse ETPs take at least 7-10 days before they shift to the DN2a stage, although progression to subsequent stages may require only $\sim 2$ days per step (Porritt et al. 2003; Manesso et al. 2013). By contrast, the ETP to DN2a transition takes no more than 1-2 days in the fetus. This postnatal-specific extension of the ETP period is poorly reproduced in the OP9-DLL1 or OP9DLL4 culture system, where most of the extended proliferation takes place in the $\mathrm{DN} 2 \mathrm{a} / 2 \mathrm{~b}$ stages. In fact, one of the differences between "ETP" cells growing on OP9-DLL1 and those harvested ex vivo is the weaker expression of
FLT3, KIT, and several other stem or progenitor-cell regulatory genes in vitro that are normally ETP specific in vivo (Zhang et al. 2012; Mingueneau et al. 2013). What is clearly missing in the OP9-DLL1 culture is an equivalent of the entry compartment. Thus, it is exciting that there is evidence that particular niches in the adult thymic microenvironment not only limit the carrying capacity of the thymus (Zietara et al. 2015) but also preserve the immature ETP status.

Normally, all entering cells differentiate or die: self-renewing stem cells do not persist in the initial entry compartment. However, two groups showed recently that the niche itself can support extremely prolonged self-renewal 
H. Hosokawa and E.V. Rothenberg

in cases where there is no competition from new waves of immigrating precursors from the bone marrow (Martins et al. 2012; Peaudecerf et al. 2012). Thus, it is possible that the initial entry compartment, the ETP niche, intrinsically supports expansion and delays differentiation. If this is true, then it provides something distinctive other than a Notch ligand. The recent definition of markers that distinguish the cells forming these initial entry niches (Buono et al. 2016) can help greatly to characterize what these self-renewal cues may be.

Recently, cells expressing the membranebound form of Kit ligand (mKITL) were reported in a specific subdomain of the thymus, which may represent the entry port for thymus-seeding cells (Buono et al. 2016). Membrane-bound KITL is known to be more potent than secreted KITL, similar to other surface-tethered cytokines in the bone marrow microenvironment. Surprisingly, a subset of vascular endothelial cells (VECs) in the cortex specifically expresses both DLL4 Notch ligands and mKITL, and they act as a specific niche for ETP cells. VEC-specific deletion of the KitL gene results in a significant decrease of the number of ETP cells in the thymus. DN2a cells, on the other hand, are supported by IL-7-expressing cortical thymic epithelial cells (cTECs), which also express DLL4 but at lower levels than on the VECs, and express a higher fraction of KITL in the lesspotent soluble form (Buono et al. 2016). Both the $\mathrm{KITL}^{+}$VECs and the cTECs express one important lymphocyte-supporting chemokine, CXCL12 (ligand for the CXCR4 chemokine receptor), but the cTECs express much more CCL25 (ligand for the CCR9 chemokine receptor) (Buono et al. 2016), which is also important for T-cell development. These results suggest that early $\mathrm{T}$ cells migrate inside of the thymus through stage-specific niches that may provide them with differentially optimized regimes of extracellular signaling. Specific niches for DN2b, DN3, and DN4 have not been reported yet, but it is assumed that there are some niches to support their proliferation, survival, and construction of stage-specific gene regulatory networks.

Importantly, lacking the vascular endothelial entry compartment, the initial port of entry in the fetal thymus appears to be the immature cortical thymic epithelium itself. Thus, the initial compartment in which the ETP to DN2 transition occurs is different in the adult and fetal thymuses. One interesting possibility is that the lack of a VEC entry compartment itself promotes the rapid kinetics of fetal T-cell differentiation. This speculation remains to be tested, but one possibility is that signals provided by the adult entry niche actually retard dif-

Table 1. Expression of cytokine receptors in early T-cell precursors

\begin{tabular}{|c|c|c|c|c|c|c|}
\hline & ETP & $\mathrm{DN} 2 \mathrm{a}$ & $\mathrm{DN} 2 \mathrm{~b}$ & DN3a & DN3b & DN4 \\
\hline Flt3 & High $\rightarrow$ low & Neg & Neg & Neg & Neg & Neg \\
\hline Kit & High & High & Mid & Low & $\mathrm{Neg}$ & $\mathrm{Neg}$ \\
\hline IL-7R & Low & High & High & High & High & Neg \\
\hline IL-4R & High & High & High & Low & Low & Mid \\
\hline IL-9R & Low (mid in fetal) & Low (mid in fetal) & Low (mid in fetal) & Low & Low & Mid \\
\hline PDGFR $\beta$ & High & High & Mid & Mid & Low & Low \\
\hline$\gamma_{\mathrm{c}}(\mathrm{Il} 2 \mathrm{rg})$ & High & High & High & High & High & High \\
\hline IL-2R $\alpha(C D 25)$ & Low & High* & High* & High* & High $\rightarrow$ mid $^{*}$ & Neg \\
\hline IL-2R $\beta$ & Neg & Neg & Neg & Neg & Neg & Neg \\
\hline $\operatorname{PDGFR} \alpha$ & Neg & Neg & Neg & Neg & $\mathrm{Neg}$ & $\mathrm{Neg}$ \\
\hline
\end{tabular}

Data are based on RNA-seq (Zhang et al. 2012) and microarray (Mingueneau et al. 2013) measurements of messenger RNAs (mRNAs) encoding the indicated receptors. Data for early thymic progenitor (ETP) and DN2 subsets derived from fetal liver precursors were from (Zhang et al. 2012). The $\gamma \mathrm{c}$ chain (CD132, encoded by $\mathrm{Il2} r g$ ) is the common heterodimer partner of the interleukin-7 receptor (IL-7R) $\alpha$, IL-4R $\alpha$, and IL-9R $\alpha$ chains. Regarding IL-2R $\alpha$, asterisks indicate that these early T-lineage cells do not express functional IL-2 receptors even when they express high $\gamma \mathrm{c}$ and IL-2R $\alpha$, because they do not express IL-2R $\beta$, which is a required functional component of both the IL-2R and the IL-15R. Neg: Negative ( $<1 \mathrm{fpkm})$. 
Cytokines, Transcription Factors, and T-Cell Development

ferentiation to enable more extensive proliferation, and that transition out of a potentially selfrenewing early-ETP regulatory state depends on release from this compartment.

The nature of such signals is still far from clear. One approach is via analysis of receptors expressed by the ETPs themselves. Based on our
RNA-seq data, we found that ETPs express Il4ra, $P d g f r b$, and possibly Il9r (Table 1), receptors whose roles in early T-cell development have not been clarified yet (Zhang et al. 2012). Recent RNA-seq data suggest that the two niches for phase 1 cells, VEC and mTEC, differentially express Pdgf family ligands (Fig. 3). Whether or

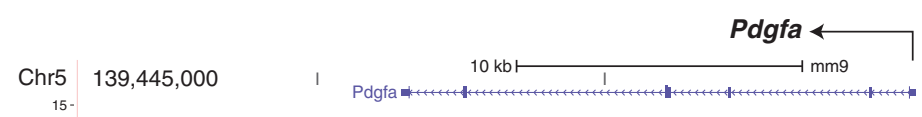

$139,480,000$

mKitL + VEC

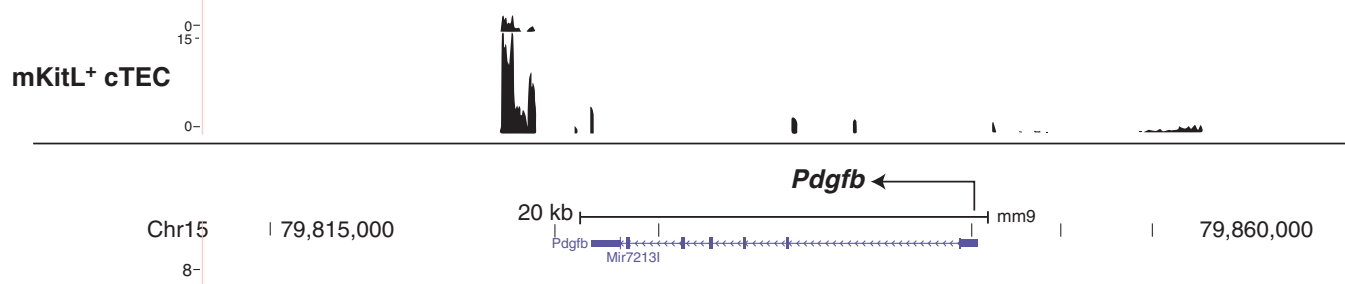

mKitL+ VEC

$8-$

mKitL+ ${ }^{+}$TEC
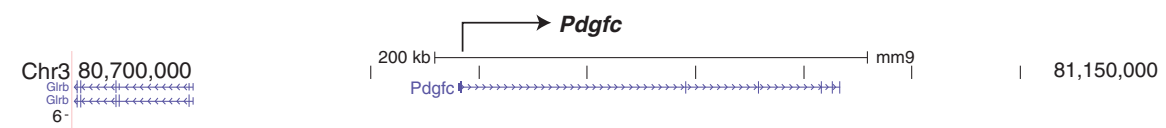

mKitL+ VEC

$0-$

mKitL ${ }^{+}$cTEC

$0_{-}$" $\quad$.

Chr9 6,000,000

8 .

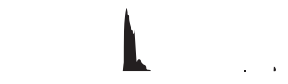

.


H. Hosokawa and E.V. Rothenberg

not these particular ligand-receptor pairs control the starting gate for T-cell development, they offer fascinating hypotheses for exploration (H Hosokawa, M Yui, and EV Rothenberg, unpubl.).

\section{CONCLUDING REMARKS}

Early T-cell development is divided into three phases, based on Notch dependency and status of T-cell commitment, and all of the three phases are essential for proper T-cell development in the thymus. Inside of the thymus, pro$\mathrm{T}$ cells undergo programmed migration and are supported by stage-specific microenvironments, which at a minimum provide Notch ligands and cytokine signaling. It is clear that stage-specific microenvironments are involved in the establishment of the stage-specific gene regulatory network. However, a great deal is yet to be explained and understood. Why is the effect of IL-7 on proliferative expansion of early $\mathrm{T}$ cells different in distinct stages? How are stage-specific transcription factors induced by extracellular signaling? And how are stage-specific roles of stably expressed transcription factors like GATA3 regulated by extracellular signaling? Are there any specific niches for DN2b, DN3, and DN4 cells as well as, possibly, for ETPs? What are the novel molecules provided by niches that support and regulate early T-cell development?

T-cell development requires a specific organ, the thymus, which provides well-regulated stage-specific microenvironments to T-cell progenitor cells. To understand T-cell development in perspective, it is important to address more deeply the molecular basis of cross talk between the extracellular signaling from the microenvironment and the cell-intrinsic gene regulatory networks in pro-T cells.

\section{ACKNOWLEDGMENTS}

The authors thank Jonas Ungerbäck and other members of the Rothenberg group for valuable discussions and advice and for sharing data before publication. Support was provided by the Manpei Suzuki Diabetes Foundation to H.H., the Albert Billings Ruddock Professorship to E.V.R., and grants from the United States Public Health Service (USPHS) to the Rothenberg Laboratory (R01 AI95943 and R01 HD76915).

\section{REFERENCES}

Agata Y, Tamaki N, Sakamoto S, Ikawa T, Masuda K, Kawamoto H, Murre C. 2007. Regulation of T cell receptor $\beta$ gene rearrangements and allelic exclusion by the helixloop-helix protein, E47. Immunity 27: 871-884.

Alves NL, Richard-Le Goff O, Huntington ND, Sousa AP, Ribeiro VS, Bordack A, Vives FL, Peduto L, Chidgey A, Cumano A, et al. 2009. Characterization of the thymic IL-7 niche in vivo. Proc Natl Acad Sci 106: 1512-1517.

Anderson G, Jenkinson WE, Jones T, Parnell SM, Kinsella FA, White AJ, Pongrac'z JE, Rossi SW, Jenkinson EJ. 2006. Establishment and functioning of intrathymic microenvironments. Immunol Rev 209: 10-27.

Balciunaite G, Ceredig R, Fehling HJ, Zúñiga-Pflücker JC, Rolink AG. 2005a. The role of Notch and IL-7 signaling in early thymocyte proliferation and differentiation. Eur J Immunol 35: 1292-1300.

Balciunaite G, Ceredig R, Rolink AG. 2005b. The earliest subpopulation of mouse thymocytes contains potent $\mathrm{T}$, significant macrophage, and natural killer cell but no B-lymphocyte potential. Blood 105: 1930-1936.

Barndt RJ, Dai M, Zhuang Y. 2000. Functions of E2A-HEB heterodimers in T-cell development revealed by a dominant negative mutation of HEB. Mol Cell Biol 20: 6677-6685.

Bell JJ, Bhandoola A. 2008. The earliest thymic progenitors for T cells possess myeloid lineage potential. Nature 452: 764-767.

Belyaev NN, Biro J, Athanasakis D, Fernandez-Reyes D, Potocnik AJ. 2012. Global transcriptional analysis of primitive thymocytes reveals accelerated dynamics of $\mathrm{T}$ cell specification in fetal stages. Immunogenetics 64: 591-604.

Boudil A, Matei IR, Shih HY, Bogdanoski G, Yuan JS, Chang SG, Montpellier B, Kowalski PE, Voisin V, Bashir S, et al. 2015. IL-7 coordinates proliferation, differentiation and Tcra recombination during thymocyte $\beta$-selection. Nat Immunol 16: 397-405.

Braunstein M, Anderson MK. 2012. HEB in the spotlight: Transcriptional regulation of T-cell specification, commitment, and developmental plasticity. Clin Dev Immunol 2012: 678-705.

Buono M, Facchini R, Matsuoka S, Thongjuea S, Waithe D, Luis TC, Giustacchini A, Besmer P, Mead AJ, Jacobsen SE, et al. 2016. A dynamic niche provides Kit ligand in a stage-specific manner to the earliest thymocyte progenitors. Nat Cell Biol 18: 157-167.

Calderon L, Boehm T. 2012. Synergistic, context-dependent, and hierarchical functions of epithelial components in thymic microenvironments. Cell 149: 159-172.

Carotta S, Dakic A, D'Amico A, Pang SH, Greig KT, Nutt SL, $\mathrm{Wu}$ L. 2010a. The transcription factor PU.1 controls dendritic cell development and Flt3 cytokine receptor expression in a dose-dependent manner. Immunity 32: 628-641. 
Carotta S, Wu L, Nutt SL. 2010b. Surprising new roles for PU.1 in the adaptive immune response. Immunol Rev 238: 63-75.

Cauchy P, Maqbool MA, Zacarias-Cabeza J, Vanhille L, Koch F, Fenouil R, Gut M, Gut I, Santana MA, Griffon A, et al. 2015. Dynamic recruitment of Ets1 to both nucleosomeoccupied and -depleted enhancer regions mediates a transcriptional program switch during early T-cell differentiation. Nucleic Acids Res 44: 3567-3585.

Champhekar A, Damle SS, Freedman G, Carotta S, Nutt SL, Rothenberg EV. 2015. Regulation of early T-lineage gene expression and developmental progression by the progenitor cell transcription factor PU.1. Genes Dev 29: $832-848$.

Chari S, Winandy S. 2008. Ikaros regulates Notch target gene expression in developing thymocytes. J Immunol 181: $6265-6274$.

Cismasiu VB, Adamo K, Gecewicz J, Duque J, Lin Q, Avram D. 2005. BCL11B functionally associates with the NuRD complex in T lymphocytes to repress targeted promoter. Oncogene 24: 6753-6764.

Cook KD, Miller J. 2010. TCR-dependent translational control of GATA-3 enhances Th2 differentiation. J Immunol 185: 3209-3216.

Dakic A, Metcalf D, Di Rago L, Mifsud S, Wu L, Nutt SL. 2005. PU.1 regulates the commitment of adult hematopoietic progenitors and restricts granulopoiesis. J Exp Med 201: 1487-1502.

David-Fung ES, Yui MA, Morales M, Wang H, Taghon T, Diamond RA, Rothenberg EV. 2006. Progression of regulatory gene expression states in fetal and adult pro-T-cell development. Immunol Rev 209: 212-236.

David-Fung ES, Butler R, Buzi G, Yui MA, Diamond RA, Anderson MK, Rowen L, Rothenberg EV. 2009. Transcription factor expression dynamics of early T-lymphocyte specification and commitment. Dev Biol 325: 444-467.

D'Cruz LM, Knell J, Fujimoto JK, Goldrath AW. 2010. An essential role for the transcription factor HEB in thymocyte survival, Tcra rearrangement and the development of natural killer T cells. Nat Immunol 11: 240-249.

Del Real MM, Rothenberg EV. 2013. Architecture of a lymphomyeloid developmental switch controlled by PU.1, Notch and Gata3. Development 140: 1207-1219.

De Obaldia ME, Bhandoola A. 2015. Transcriptional regulation of innate and adaptive lymphocyte lineages. Annu Rev Immunol 33: 607-642.

De Obaldia ME, Bell JJ, Bhandoola A. 2013a. Early T-cell progenitors are the major granulocyte precursors in the adult mouse thymus. Blood 121: 64-71.

De Obaldia ME, Bell JJ, Wang X, Harly C, Yashiro-Ohtani Y, Delong JH, Zlotoff DA, Sultana DA, Pear WS, Bhandoola A. 2013b. T cell development requires constraint of the myeloid regulator C/EBP- $\alpha$ by the Notch target and transcriptional repressor Hes1. Nat Immunol 14: 1277-1284.

Diefenbach A, Colonna M, Koyasu S. 2014. Development, differentiation, and diversity of innate lymphoid cells. Immunity 41: 354-365.

DiSanto JP, Muller W, Guy-Grand D, Fischer A, Rajewsky K. 1995. Lymphoid development in mice with a targeted deletion of the interleukin 2 receptor $\gamma$ chain. Proc Natl Acad Sci 92: 377-381.
Engel I, Murre C. 2004. E2A proteins enforce a proliferation checkpoint in developing thymocytes. EMBO J 23: 202211.

Franco CB, Scripture-Adams DD, Proekt I, Taghon T, Weiss AH, Yui MA, Adams SL, Diamond RA, Rothenberg EV. 2006. Notch/ $\Delta$ signaling constrains reengineering of proT cells by PU.1. Proc Natl Acad Sci 103: 11993-11998.

Garcia-Ojeda ME, Klein Wolterink RG, Lemaitre F, RichardLe Goff O, Hasan M, Hendriks RW, Cumano A, Di Santo JP. 2013. GATA-3 promotes T-cell specification by repressing B-cell potential in pro-T cells in mice. Blood 121: 1749-1759.

Geimer Le Lay AS, Oravecz A, Mastio J, Jung C, Marchal P, Ebel C, Dembélé D, Jost B, Le Gras S, Thibault C, et al. 2014. The tumor suppressor Ikaros shapes the repertoire of Notch target genes in T cells. Sci Signal 7: ra28.

Georgescu C, Longabaugh WJ, Scripture-Adams DD, David-Fung ES, Yui MA, Zarnegar MA, Bolouri H, Rothenberg EV. 2008. A gene regulatory network armature for T lymphocyte specification. Proc Natl Acad Sci 105: 20100-20105.

Germar K, Dose M, Konstantinou T, Zhang J, Wang H, Lobry C, Arnett KL, Blacklow SC, Aifantis I, Aster JC, et al. 2011. T-cell factor 1 is a gatekeeper for T-cell specification in response to Notch signaling. Proc Natl Acad Sci 108: 20060-20065.

Goodings C, Smith E, Mathias E, Elliott N, Cleveland SM, Tripathi RM, Layer JH, Chen X, Guo Y, Shyr Y, et al. 2015. Hhex is required at multiple stages of adult hematopoietic stem and progenitor cell differentiation. Stem Cells 33: $2628-2641$.

Griffith AV, Fallahi M, Nakase H, Gosink M, Young B, Petrie HT. 2009. Spatial mapping of thymic stromal microenvironments reveals unique features influencing Tlymphoid differentiation. Immunity 31: 999-1009.

Gu TL, Goetz TL, Graves BJ, Speck NA. 2000. Auto-inhibition and partner proteins, core-binding factor $\beta(\mathrm{CBF} \beta)$ and Ets-1, modulate DNA binding by CBF 2 (AML1). Mol Cell Biol 20: 91-103.

Hayday AC, Pennington DJ. 2007. Key factors in the organized chaos of early T cell development. Nat Immunol 8: 137-144.

Heinzel K, Benz C, Martins VC, Haidl ID, Bleul CC. 2007. Bone marrow-derived hemopoietic precursors commit to the $\mathrm{T}$ cell lineage only after arrival in the thymic microenvironment. J Immunol 178: 858-868.

Hernandez-Hernandez A, Ray P, Litos G, Ciro M, Ottolenghi S, Beug H, Boyes J. 2006. Acetylation and MAPK phosphorylation cooperate to regulate the degradation of active GATA-1. EMBO J 25: 3264-3274.

Hosokawa H, Kato M, Tohyama H, Tamaki Y, Endo Y, Kimura MY, Tumes DJ, Motohashi S, Matsumoto M, Nakayama KI, et al. 2015. Methylation of Gata3 protein at Arg-261 regulates transactivation of the Il5 gene in T helper 2 cells. J Biol Chem 290: 13095-13103.

Hosokawa H, Tanaka T, Endo Y, Kato M, Shinoda K, Suzuki A, Motohashi S, Matsumoto M, Nakayama KI, Nakayama T. 2016. Akt1-mediated Gata3 phosphorylation controls the repression of IFN $\gamma$ in memory-type Th2 cells. Nat Commun 7: 11289.

Hosoya T, Kuroha T, Moriguchi T, Cummings D, Maillard I, Lim KC, Engel JD. 2009. GATA-3 is required for early T 
H. Hosokawa and E.V. Rothenberg

lineage progenitor development. J Exp Med 206: 2987 3000.

Hosoya T, Maillard I, Engel JD. 2010. From the cradle to the grave: Activities of GATA-3 throughout T-cell development and differentiation. Immunol Rev 238: 110-125.

Hoyler T, Klose CS, Souabni A, Turqueti-Neves A, Pfeifer D, Rawlins EL, Voehringer D, Busslinger M, Diefenbach A. 2012. The transcription factor GATA-3 controls cell fate and maintenance of type 2 innate lymphoid cells. Immunity 37: 634-648.

Hozumi K, Negishi N, Tsuchiya I, Abe N, Hirano K, Suzuki D, Yamamoto M, Engel JD, Habu S. 2008. Notch signaling is necessary for GATA3 function in the initiation of T cell development. Eur J Immunol 38: 977-985.

Huang J, Garrett KP, Pelayo R, Zúñiga-Pflücker JC, Petrie HT, Kincade PW. 2005. Propensity of adult lymphoid progenitors to progress to DN2/3 stage thymocytes with Notch receptor ligation. J Immunol 175: 4858-4865.

Huang G, Zhang P, Hirai H, Elf S, Yan X, Chen Z, Koschmieder S, Okuno Y, Dayaram T, Growney JD, et al. 2008. PU.1 is a major downstream target of AML1 (RUNX1) in adult mouse hematopoiesis. Nat Genet 40: 51-60.

Ikawa T, Kawamoto H, Goldrath AW, Murre C. 2006. E proteins and Notch signaling cooperate to promote T cell lineage specification and commitment. J Exp Med 203: $1329-1342$.

Ikawa T, Hirose S, Masuda K, Kakugawa K, Satoh R, Shibano-Satoh A, Kominami R, Katsura Y, Kawamoto H. 2010. An essential developmental checkpoint for production of the T cell lineage. Science 329: 93-96.

Jackson JT, Nasa C, Shi W, Huntington ND, Bogue CW, Alexander WS, McCormack MP. 2015. A crucial role for the homeodomain transcription factor Hhex in lymphopoiesis. Blood 125: 803-814.

Jahn T, Sindhu S, Gooch S, Seipel P, Lavori P, Leifheit E, Weinberg K. 2007. Direct interaction between Kit and the interleukin-7 receptor. Blood 110: 1840-1847.

Janas ML, Varano G, Gudmundsson K, Noda M, Nagasawa T, Turner M. 2010. Thymic development beyond $\beta$-selection requires phosphatidylinositol 3-kinase activation by CXCR4. J Exp Med 207: 247-261.

Kang J, DiBenedetto B, Narayan K, Zhao H, Der SD, Chambers CA. 2004. STAT5 is required for thymopoiesis in a development stage-specific manner. J Immunol 173: 2307-2314.

Kitagawa K, Shibata K, Matsumoto A, Matsumoto M, Ohhata T, Nakayama KI, Niida H, Kitagawa M. 2014. Fbw7 targets GATA3 through cyclin-dependent kinase 2dependent proteolysis and contributes to regulation of T-cell development. Mol Cell Biol 34: 2732-2744.

Kleinmann E, Geimer Le Lay AS, Sellars M, Kastner P, Chan S. 2008. Ikaros represses the transcriptional response to Notch signaling in T-cell development. Mol Cell Biol 28: 7465-7475.

Knudsen KJ, Rehn M, Hasemann MS, Rapin N, Bagger FO, Ohlsson E, Willer A, Frank AK, Sondergaard E, Jendholm J, et al. 2015. ERG promotes the maintenance of hematopoietic stem cells by restricting their differentiation. Genes Dev 29: 1915-1929.

Kreslavsky T, Gleimer M, Miyazaki M, Choi Y, Gagnon E, Murre C, Sicinski P, von Boehmer H. 2012. $\beta$-Selection- induced proliferation is required for $\alpha \beta$ T cell differentiation. Immunity 37: 840-853.

Krueger A, Willenzon S, Lyszkiewicz M, Kremmer E, Förster R. 2010. CC chemokine receptor 7 and 9 double-deficient hematopoietic progenitors are severely impaired in seeding the adult thymus. Blood 115: 1906-1912.

Kueh HY, Yui MA, Ng KKH, Zhang JA, Pease SS, Damle SS, Freedman G, Siu S, Bernstein ID, Elowitz MB, et al. 2016 Asynchronous combinatorial action of four regulatory factors activates $B c l 11 b$ for T cell commitment. Nat Immunol 17: 956-965.

Laiosa CV, Stadtfeld M, Xie H, de Andres-Aguayo L, Graf T. 2006. Reprogramming of committed $\mathrm{T}$ cell progenitors to macrophages and dendritic cells by C/EBP $\alpha$ and PU.1 transcription factors. Immunity 25: 731-744.

Lefebvre JM, Haks MC, Carleton MO, Rhodes M, Sinnathamby G, Simon MC, Eisenlohr LC, Garrett-Sinha LA, Wiest DL. 2005. Enforced expression of Spi-B reverses T lineage commitment and blocks $\beta$-selection. J Immunol 174: 6184-6194.

Li Z, Dordai DI, Lee J, Desiderio S. 1996. A conserved degradation signal regulates RAG-2 accumulation during cell division and links $\mathrm{V}(\mathrm{D}) \mathrm{J}$ recombination to the cell cycle. Immunity 5: 575-589.

Li L, Leid M, Rothenberg EV. 2010a. An early T cell lineage commitment checkpoint dependent on the transcription factor Bcl11b. Science 329: 89-93.

Li P, Burke S, Wang J, Chen X, Ortiz M, Lee SC, Lu D, Campos L, Goulding D, Ng BL, et al. 2010b. Reprogramming of T cells to natural killer-like cells upon Bcl11b deletion. Science 329: 85-89.

Li L, Zhang JA, Dose M, Kueh HY, Mosadeghi R, Gounari F, Rothenberg EV. 2013. A far downstream enhancer for murine Bcl11b controls its T-cell specific expression. Blood 122: 902-911.

Longabaugh WJR, Zeng W, Zhang JA, Hosokawa H, Jansen C, Li L, Romero-Wolf M, Liu P, Kueh HY, Mortazavi A, Rothenberg EV. 2017. Bcl1 1b and combinatorial resolution of cell fate in the T-cell gene regulatory network. Proc Natl Acad Sci 114: 5800-5807.

Love PE, Bhandoola A. 2011. Signal integration and crosstalk during thymocyte migration and emigration. Nat Rev Immunol 11: 469-477.

Lu M, Tayu R, Ikawa T, Masuda K, Matsumoto I, Mugishima H, Kawamoto H, Katsura Y. 2005. The earliest thymic progenitors in adults are restricted to T, NK, and dendritic cell lineage and have a potential to form more diverse TCR $\beta$ chains than fetal progenitors. J Immunol 175: $5848-5856$.

Luc S, Luis TC, Boukarabila H, Macaulay IC, Buza-Vidas N, Bouriez-Jones T, Lutteropp M, Woll PS, Loughran SJ, Mead AJ, et al. 2012. The earliest thymic T cell progenitors sustain B cell and myeloid lineage potential. Nat Immunol 13: 412-419.

Lyszkiewicz M, Zietara N, Fohse L, Puchalka J, Diestelhorst J, Witzlau K, Prinz I, Schambach A, Krueger A. 2015. Limited niche availability suppresses murine intrathymic dendritic-cell development from noncommitted progenitors. Blood 125: 457-464.

Maillard I, Tu L, Sambandam A, Yashiro-Ohtani Y, Millholland J, Keeshan K, Shestova O, Xu L, Bhandoola A, Pear WS. 2006. The requirement for Notch signaling at the 
$\beta$-selection checkpoint in vivo is absolute and independent of the pre-T cell receptor. J Exp Med 203: 22392245.

Manesso E, Chickarmane V, Kueh HY, Rothenberg EV, Peterson C. 2013. Computational modelling of T-cell formation kinetics: Output regulated by initial proliferation-linked deferral of developmental competence. $J R$ Soc Interface 10: 20120774.

Martins VC, Ruggiero E, Schlenner SM, Madan V, Schmidt M, Fink PJ, von Kalle C, Rodewald HR. 2012. Thymusautonomous $\mathrm{T}$ cell development in the absence of progenitor import. J Exp Med 209: 1409-1417.

Massa S, Balciunaite G, Ceredig R, Rolink AG. 2006. Critical role for c-kit (CD117) in T cell lineage commitment and early thymocyte development in vitro. Eur J Immunol 36: $526-532$.

Masuda K, Kakugawa K, Nakayama T, Minato N, Katsura Y, Kawamoto H. 2007. T cell lineage determination precedes the initiation of TCR $\beta$ gene rearrangement. J Immunol 179: 3699-3706.

Mingueneau M, Kreslavsky T, Gray D, Heng T, Cruse R, Ericson J, Bendall S, Spitzer MH, Nolan GP, Kobayashi $\mathrm{K}$, et al. 2013. The transcriptional landscape of $\alpha \beta \mathrm{T}$ cell differentiation. Nat Immunol 14: 619-632.

Mohtashami M, Shah DK, Nakase H, Kianizad K, Petrie HT Zúñiga-Pflücker JC. 2010. Direct comparison of Dll1and Dll4-mediated Notch activation levels shows differential lymphomyeloid lineage commitment outcomes. J Immunol 185: 867-876.

Naito T, Tanaka H, Naoe Y, Taniuchi I. 2011. Transcriptional control of T-cell development. Int Immunol 23: 661-668.

Nie L, Perry SS, Zhao Y, Huang J, Kincade PW, Farrar MA, Sun XH. 2008. Regulation of lymphocyte development by cell-type-specific interpretation of Notch signals. Mol Cell Biol 28: 2078-2090.

Noguchi M, Yi H, Rosenblatt HM, Filipovich AH, Adelstein S, Modi WS, McBride OW, Leonard WJ. 1993. Interleukin-2 receptor $\gamma$ chain mutation results in X-linked severe combined immunodeficiency in humans. Cell 73: $147-$ 157.

Oosterwegel M, van de Wetering M, Dooijes D, Klomp L, Winoto A, Georgopoulos K, Meijlink F, Clevers H. 1991. Cloning of murine TCF-1, a T cell-specific transcription factor interacting with functional motifs in the CD3- $\varepsilon$ and T cell receptor $\alpha$ enhancers. J Exp Med 173: $1133-$ 1142.

Pai SY, Truitt ML, Ting CN, Leiden JM, Glimcher LH, Ho IC. 2003. Critical roles for transcription factor GATA-3 in thymocyte development. Immunity 19: 863-875.

Pallard C, Stegmann AP, van Kleffens T, Smart F, Venkitaraman A, Spits H. 1999. Distinct roles of the phosphatidylinositol 3-kinase and STAT5 pathways in IL-7-mediated development of human thymocyte precursors. Immunity 10: $525-535$.

Peaudecerf L, Lemos S, Galgano A, Krenn G, Vasseur F, Di Santo JP, Ezine S, Rocha B. 2012. Thymocytes may persist and differentiate without any input from bone marrow progenitors. J Exp Med 209: 1401-1408.

Peschon JJ, Morrissey PJ, Grabstein KH, Ramsdell FJ, Maraskovsky E, Gliniak BC, Park LS, Ziegler SF, Williams DE, Ware CB, et al. 1994. Early lymphocyte expansion is se- verely impaired in interleukin 7 receptor-deficient mice. J Exp Med 180: 1955-1960.

Petrie HT, Zúñiga-Pflücker JC. 2007. Zoned out: Functional mapping of stromal signaling microenvironments in the thymus. Annu Rev Immunol 25: 649-679.

Porritt HE, Gordon K, Petrie HT. 2003. Kinetics of steadystate differentiation and mapping of intrathymic-signaling environments by stem cell transplantation in nonirradiated mice. J Exp Med 198: 957-962.

Prinz I, Silva-Santos B, Pennington DJ. 2013. Functional development of $\gamma \delta$ T cells. Eur J Immunol 43: 1988-1994.

Prockop SE, Petrie HT. 2004. Regulation of thymus size by competition for stromal niches among early $\mathrm{T}$ cell progenitors. J Immunol 173: 1604-1611.

Puel A, Ziegler SF, Buckley RH, Leonard WJ. 1998. Defective IL7R expression in $\mathrm{T}^{-} \mathrm{B}^{+} \mathrm{NK}^{+}$severe combined immunodeficiency. Nat Genet 20: 394-397.

Radtke F, Fasnacht N, MacDonald HR. 2010. Notch signaling in the immune system. Immunity 32: 14-27.

Ramond C, Berthault C, Burlen-Defranoux O, de Sousa AP, Guy-Grand D, Vieira P, Pereira P, Cumano A. 2014. Two waves of distinct hematopoietic progenitor cells colonize the fetal thymus. Nat Immunol 15: 27-35.

Rosenbauer F, Owens BM, Yu L, Tumang JR, Steidl U, Kutok JL, Clayton LK, Wagner K, Scheller M, Iwasaki H, et al. 2006. Lymphoid cell growth and transformation are suppressed by a key regulatory element of the gene encoding PU.1. Nat Genet 38: 27-37.

Rothenberg EV. 2000. Stepwise specification of lymphocyte developmental lineages. Curr Opin Genet Dev 10: 370 379.

Rothenberg EV. 2014. Transcriptional control of early T and B cell developmental choices. Annu Rev Immunol 32: 283-321.

Rothenberg EV, Moore JE, Yui MA. 2008. Launching the T-cell-lineage developmental programme. Nat Rev Immunol 8: 9-21.

Sambandam A, Maillard I, Zediak VP, Xu L, Gerstein RM, Aster JC, Pear WS, Bhandoola A. 2005. Notch signaling controls the generation and differentiation of early $\mathrm{T}$ lineage progenitors. Nat Immunol 6: 663-670.

Schlenner SM, Madan V, Busch K, Tietz A, Laufle C, Costa C, Blum C, Fehling HJ, Rodewald HR. 2010. Fate mapping reveals separate origins of $\mathrm{T}$ cells and myeloid lineages in the thymus. Immunity 32: 426-436.

Schmitt TM, Zúñiga-Pflücker JC. 2002. Induction of T cell development from hematopoietic progenitor cells by Delta-like-1 in vitro. Immunity 17: 749-756.

Schmitt TM, Ciofani M, Petrie HT, Zúñiga-Pflücker JC. 2004. Maintenance of T cell specification and differentiation requires recurrent Notch receptor-ligand interactions. J Exp Med 200: 469-479.

Schwartz R, Engel I, Fallahi-Sichani M, Petrie HT, Murre C. 2006. Gene expression patterns define novel roles for $\mathrm{E} 47$ in cell cycle progression, cytokine-mediated signaling, and T lineage development. Proc Natl Acad Sci 103: 9976-9981.

Schwarz BA, Sambandam A, Maillard I, Harman BC, Love PE, Bhandoola A. 2007. Selective thymus settling regulated by cytokine and chemokine receptors. J Immunol 178: 2008-2017. 
H. Hosokawa and E.V. Rothenberg

Scripture-Adams DD, Damle SS, Li L, Elihu KJ, Qin S, Arias AM, Butler RR III, Champhekar A, Zhang JA, Rothenberg EV. 2014. GATA-3 dose-dependent checkpoints in early T cell commitment. J Immunol 193: 3470-3491.

Serafini N, Vosshenrich CA, Di Santo JP. 2015. Transcriptional regulation of innate lymphoid cell fate. Nat Rev Immunol 15: 415-428.

Shen HQ, Lu M, Ikawa T, Masuda K, Ohmura K, Minato N, Katsura Y, Kawamoto H. 2003. T/NK bipotent progenitors in the thymus retain the potential to generate dendritic cells. J Immunol 171: 3401-3406.

Singer A, Adoro S, Park JH. 2008. Lineage fate and intense debate: Myths, models and mechanisms of CD4- versus CD8-lineage choice. Nat Rev Immunol 8: 788-801.

Sun Z, Unutmaz D, Zou YR, Sunshine MJ, Pierani A, Brenner-Morton S, Mebius RE, Littman DR. 2000. Requirement for ROR $\gamma$ in thymocyte survival and lymphoid organ development. Science 288: 2369-2373.

Tabrizifard S, Olaru A, Plotkin J, Fallahi-Sichani M, Livak F, Petrie HT. 2004. Analysis of transcription factor expression during discrete stages of postnatal thymocyte differentiation. J Immunol 173: 1094-1102.

Taghon T, Yui MA, Pant R, Diamond RA, Rothenberg EV. 2006. Developmental and molecular characterization of emerging $\beta$ - and $\gamma \delta$-selected pre-T cells in the adult mouse thymus. Immunity 24: 53-64.

Taghon T, Yui MA, Rothenberg EV. 2007. Mast cell lineage diversion of $\mathrm{T}$ lineage precursors by the essential $\mathrm{T}$ cell transcription factor GATA-3. Nat Immunol 8: 845-855.

Takeuchi A, Yamasaki S, Takase K, Nakatsu F, Arase H, Onodera M, Saito T. 2001. E2A and HEB activate the pre-TCR $\alpha$ promoter during immature T cell development. J Immunol 167: 2157-2163.

Thompson PK, Zúñiga-Pflücker JC. 2011. On becoming a T cell, a convergence of factors kick it up a Notch along the way. Semin Immunol 23: 350-359.

Tindemans I, Serafini N, Di Santo JP, Hendriks RW. 2014. GATA-3 function in innate and adaptive immunity. Immunity 41: 191-206.

Tussiwand R, Engdahl C, Gehre N, Bosco N, Ceredig R, Rolink AG. 2011. The preTCR-dependent DN3 to DP transition requires Notch signaling, is improved by CXCL12 signaling and is inhibited by IL-7 signaling. Eur J Immunol 41: 3371-3380.

Tydell CC, David-Fung ES, Moore JE, Rowen L, Taghon T, Rothenberg EV. 2007. Molecular dissection of prethymic progenitor entry into the $\mathrm{T}$ lymphocyte developmental pathway. J Immunol 179: 421-438.

Uehara S, Grinberg A, Farber JM, Love PE. 2002. A role for CCR9 in T lymphocyte development and migration. J Immunol 168: 2811-2819.

Van de Walle I, De Smet G, Gartner M, De Smedt M, Waegemans E, Vandekerckhove B, Leclercq G, Plum J, Aster JC, Bernstein ID, et al. 2011. Jagged2 acts as a Delta-like Notch ligand during early hematopoietic cell fate decisions. Blood 117: 4449-4459.

Vantourout P, Hayday A. 2013. Six-of-the-best: Unique contributions of $\gamma \delta$ T cells to immunology. Nat Rev Immunol 13: $88-100$.

Vigano MA, Ivanek R, Balwierz P, Berninger P, van Nimwegen E, Karjalainen K, Rolink A. 2014. An epigenetic pro- file of early T-cell development from multipotent progenitors to committed T-cell descendants. Eur J Immunol 44: 1181-1193.

von Freeden-Jeffry U, Vieira P, Lucian LA, McNeil T, Burdach SE, Murray R. 1995. Lymphopenia in interleukin (IL)-7 gene-deleted mice identifies IL-7 as a nonredundant cytokine. J Exp Med 181: 1519-1526.

Wada H, Masuda K, Satoh R, Kakugawa K, Ikawa T, Katsura Y, Kawamoto H. 2008. Adult T-cell progenitors retain myeloid potential. Nature 452: 768-772.

Walker JA, Oliphant CJ, Englezakis A, Yu Y, Clare S, Rodewald HR, Belz G, Liu P, Fallon PG, McKenzie ANJ. 2015. Bcll1b is essential for group 2 innate lymphoid cell development. J Exp Med 212: 875-882.

Wang H, Pierce LJ, Spangrude GJ. 2006. Distinct roles of IL7 and stem cell factor in the OP9-DL1 T-cell differentiation culture system. Exp Hematol 34: 1730-1740.

Wang R, Xie H, Huang Z, Ma J, Fang X, Ding Y, Sun Z. 2011. Transcription factor network regulating $\mathrm{CD} 4^{+} \mathrm{CD} 8^{+}$thymocyte survival. Crit Rev Immunol 31: 447-458.

Waskow C, Paul S, Haller C, Gassmann M, Rodewald HR. 2002. Viable $\mathrm{c}-\mathrm{Kit}^{\mathrm{W} / \mathrm{W}}$ mutants reveal pivotal role for c-kit in the maintenance of lymphopoiesis. Immunity 17: $277-288$.

Watanabe Y, Aiba Y, Katsura Y. 1997. T cell progenitors in the murine fetal liver: Differences from those in the adult bone marrow. Cell Immunol 177: 18-25.

Weber BN, Chi AW, Chavez A, Yashiro-Ohtani Y, Yang Q, Shestova O, Bhandoola A. 2011. A critical role for TCF-1 in T-lineage specification and differentiation. Nature 476: $63-68$.

Welinder E, Mansson R, Mercer EM, Bryder D, Sigvardsson M, Murre C. 2011. The transcription factors E2A and $\mathrm{HEB}$ act in concert to induce the expression of FOXO1 in the common lymphoid progenitor. Proc Natl Acad Sci 108: $17402-17407$.

Wojciechowski J, Lai A, Kondo M, Zhuang Y. 2007. E2A and HEB are required to block thymocyte proliferation prior to pre-TCR expression. J Immunol 178: 5717-5726.

Wong SH, Walker JA, Jolin HE, Drynan LF, Hams E, Camelo A, Barlow JL, Neill DR, Panova V, Koch U, et al. 2012. Transcription factor ROR $\alpha$ is critical for nuocyte development. Nat Immunol 13: 229-236.

Xu W, Carr T, Ramirez K, McGregor S, Sigvardsson M, Kee BL. 2013. E2A transcription factors limit expression of Gata3 to facilitate T lymphocyte lineage commitment. Blood 121: 1534-1542.

Yang Q, Jeremiah Bell J, Bhandoola A. 2010. T-cell lineage determination. Immunol Rev 238: 12-22.

Yang Q, Monticelli LA, Saenz SA, Chi AW, Sonnenberg GF, Tang J, De Obaldia ME, Bailis W, Bryson JL, Toscano K, et al. 2013. T cell factor 1 is required for group 2 innate lymphoid cell generation. Immunity 38: 694-704.

Yao Z, Cui Y, Watford WT, Bream JH, Yamaoka K, Hissong BD, Li D, Durum SK, Jiang Q, Bhandoola A, et al. 2006. Stat $5 \mathrm{a} / \mathrm{b}$ are essential for normal lymphoid development and differentiation. Proc Natl Acad Sci 103: 1000-1005.

Yashiro-Ohtani Y, He Y, Ohtani T, Jones ME, Shestova O, Xu L, Fang TC, Chiang MY, Intlekofer AM, Blacklow SC, et al. 2009. Pre-TCR signaling inactivates Notch1 transcription by antagonizing E2A. Genes Dev 23: 1665-1676. 
Ye SK, Agata Y, Lee HC, Kurooka H, Kitamura T, Shimizu A, Honjo T, Ikuta K. 2001. The IL-7 receptor controls the accessibility of the TCR $\gamma$ locus by Stat5 and histone acetylation. Immunity 15: 813-823.

Yu Q, Erman B, Park JH, Feigenbaum L, Singer A. 2004. IL-7 receptor signals inhibit expression of transcription factors TCF-1, LEF-1, and ROR $\gamma$ t: Impact on thymocyte development. J Exp Med 200: 797-803.

Yu Q, Sharma A, Sen JM. 2010. TCF1 and $\beta$-catenin regulate T cell development and function. Immunol Res 47: 45-55.

Yu Y, Wang C, Clare S, Wang J, Lee SC, Brandt C, Burke S, Lu L, He D, Jenkins NA, et al. 2015. The transcription factor Bcll1b is specifically expressed in group 2 innate lymphoid cells and is essential for their development. J Exp Med 212: 865-874.

Yuan J, Crittenden RB, Bender TP. 2010. c-Myb promotes the survival of $\mathrm{CD} 4^{+} \mathrm{CD} 8{ }^{+}$double-positive thymocytes through upregulation of Bcl-xL. J Immunol 184: 27932804.

Yui MA, Rothenberg EV. 2004. Deranged early T cell development in immunodeficient strains of nonobese diabetic mice. J Immunol 173: 5381-5391.

Yui MA, Rothenberg EV. 2014. Developmental gene networks: A triathlon on the course to T cell identity. Nat Rev Immunol 14: 529-545.

Zamisch M, Moore-Scott B, Su DM, Lucas PJ, Manley N, Richie ER. 2005. Ontogeny and regulation of IL-7expressing thymic epithelial cells. J Immunol 174: 60-67.
Zarnegar MA, Chen J, Rothenberg EV. 2010. Cell-type-specific activation and repression of PU.1 by a complex of discrete, functionally specialized cis-regulatory elements. Mol Cell Biol 30: 4922-4939.

Zhang JA, Mortazavi A, Williams BA, Wold BJ, Rothenberg EV. 2012. Dynamic transformations of genome-wide epigenetic marking and transcriptional control establish T cell identity. Cell 149: 467-482.

Zhong C, Zhu J. 2015. Bcl11b drives the birth of ILC2 innate lymphocytes. J Exp Med 212: 828.

Zhong Y, Jiang L, Hiai H, Toyokuni S, Yamada Y. 2007. Overexpression of a transcription factor LYL1 induces T- and B-cell lymphoma in mice. Oncogene 26: 69376947.

Zietara N, Lyszkiewicz M, Puchalka J, Witzlau K, Reinhardt A, Forster R, Pabst O, Prinz I, Krueger A. 2015. Multicongenic fate mapping quantification of dynamics of thymus colonization. J Exp Med 212: 1589-1601.

Zlotoff DA, Sambandam A, Logan TD, Bell JJ, Schwarz BA, Bhandoola A. 2010. CCR7 and CCR9 together recruit hematopoietic progenitors to the adult thymus. Blood 115: 1897-1905.

Zohren F, Souroullas GP, Luo M, Gerdemann U, Imperato MR, Wilson NK, Göttgens B, Lukov GL, Goodell MA. 2012. The transcription factor Lyl-1 regulates lymphoid specification and the maintenance of early $\mathrm{T}$ lineage progenitors. Nat Immunol 13: 761-769. 


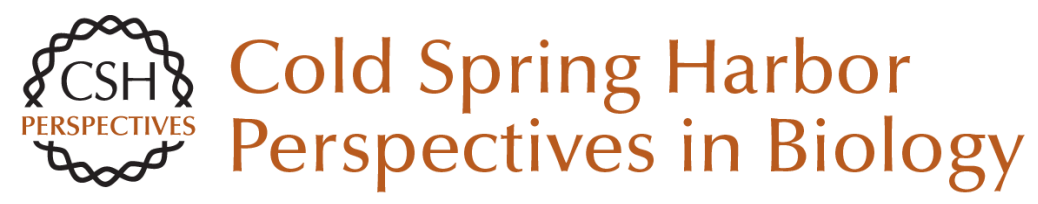

\title{
Cytokines, Transcription Factors, and the Initiation of T-Cell Development
}

\author{
Hiroyuki Hosokawa and Ellen V. Rothenberg
}

Cold Spring Harb Perspect Biol 2018; doi: 10.1101/cshperspect.a028621 originally published online July 17,2017

\section{Subject Collection Cytokines}

Interleukin (IL)-33 and the IL-1 Family of Cytokines

--Regulators of Inflammation and Tissue

Homeostasis

Ajithkumar Vasanthakumar and Axel Kallies

Targeting IL-10 Family Cytokines for the Treatment of Human Diseases

Xiaoting Wang, Kit Wong, Wenjun Ouyang, et al.

\section{Cytokine-Mediated Regulation of CD8 T-Cell} Responses During Acute and Chronic Viral Infection

Masao Hashimoto, Se Jin Im, Koichi Araki, et al.

Cytokines in Cancer Immunotherapy

Thomas A. Waldmann

The Tumor Necrosis Factor Family: Family Conventions and Private Idiosyncrasies David Wallach

The Interferon (IFN) Class of Cytokines and the IFN Regulatory Factor (IRF) Transcription Factor Family

Hideo Negishi, Tadatsugu Taniguchi and Hideyuki Yanai
Interferon $\gamma$ and Its Important Roles in Promoting and Inhibiting Spontaneous and Therapeutic Cancer Immunity

Elise Alspach, Danielle M. Lussier and Robert D. Schreiber

Inflammasome-Dependent Cytokines at the Crossroads of Health and Autoinflammatory Disease

Hanne Van Gorp, Nina Van Opdenbosch and Mohamed Lamkanfi

Innate Lymphoid Cells (ILCs): Cytokine Hubs

Regulating Immunity and Tissue Homeostasis Maho Nagasawa, Hergen Spits and Xavier Romero Ros

T Helper Cell Differentiation, Heterogeneity, and

Plasticity Jinfang Zhu

Development, Diversity, and Function of Dendritic

Cells in Mouse and Human

David A. Anderson III, Kenneth M. Murphy and Carlos G. Briseño

Cytokines and Long Noncoding RNAs Susan Carpenter and Katherine A. Fitzgerald

For additional articles in this collection, see http://cshperspectives.cshlp.org/cgi/collection/

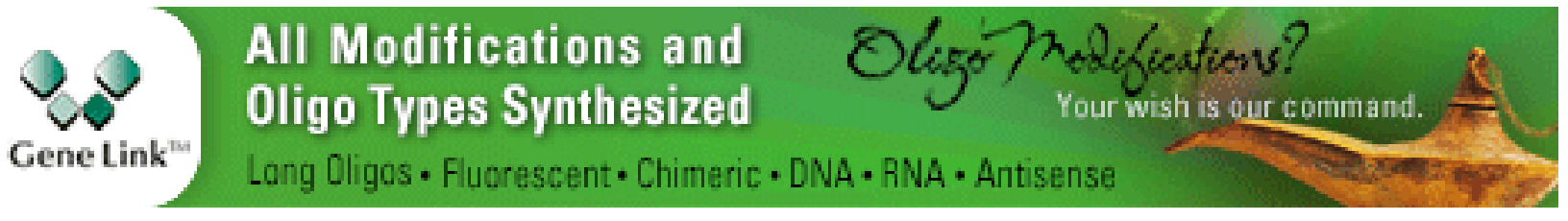


Role of the $\beta$ Common $(\beta \mathrm{c})$ Family of Cytokines in Health and Disease

Timothy R. Hercus, Winnie L. T. Kan, Sophie E. Broughton, et al.

Interleukin (IL)-12 and IL-23 and Their Conflicting Roles in Cancer Juming Yan, Mark J. Smyth and Michele W.L. Teng
Negative Regulation of Cytokine Signaling in Immunity

Akihiko Yoshimura, Minako Ito, Shunsuke Chikuma, et al.

Cancer Inflammation and Cytokines

Maria Rosaria Galdiero, Gianni Marone and Alberto Mantovani

For additional articles in this collection, see http://cshperspectives.cshlp.org/cgi/collection/

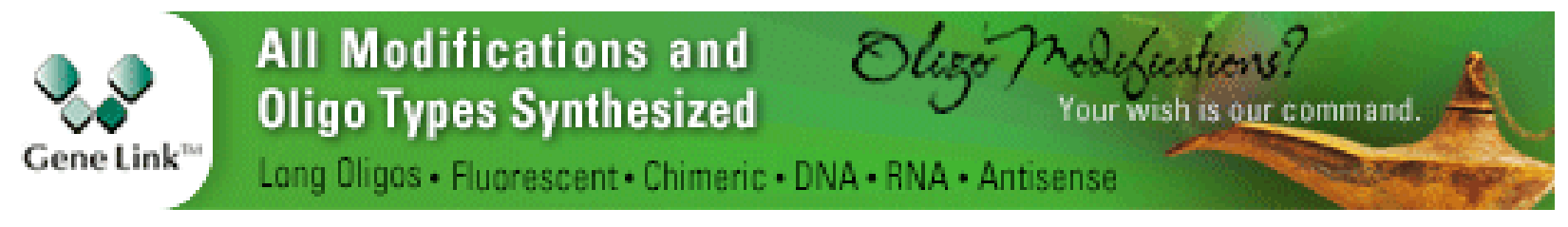

Copyright @ 2018 Cold Spring Harbor Laboratory Press; all rights reserved 